\title{
KONSEP MEDIA PEMBELAJARAN PAUD
}

\author{
Asmariani \\ Dosen Manajemen Pendidikan Islam \\ Fakultas Ilmu Agama Islam, Unversitas Islam Indragiri
}

\begin{abstract}
Abstrak
Media pembelajaran adalah segala bentuk alat komunikasi yang dapat digunakan untuk menyampaikan pesan/informasi dari sumber kepada anak didik yang bertujuan agar dapat merangsang pikiran, perasaan, minat dan perhatian anak didik untuk mengikuti kegiatan pembelajaran. Media memegang peranan penting dalam proses pembelajaran pada anak usia dini. Media pembelajaran merupakan bagian yang integral dari seluruh sistem pembelajaran. Penggunaan media pembelajaran dalam kegiatan belajar mengajar memiliki pengaruh yang cukup besar terhadap fungsi alat indra murid. Penggunaan media akan lebih menjamin terjadinya pemahaman dan retensi yang lebih baik terhadap isi pelajaran. Media pembelajaran juga mampu membangkitkan dan membawa murid ke dalam suasana senang dan gembira. Adanya keterlibatan emosional dan mental tentu hal ini berpengaruh terhadap semangat mereka untuk lebih giat dalam belajar sehingga dapat memberikan kesan pembelajaran yang hidup, akhirnya bermuara kepada peningkatan pemahaman belajar anak terhadap materi ajar. Jadi sasaran akhir media adalah memudahkan belajar untuk murid, bukan hanya kemudahan mengajar oleh guru.
\end{abstract}

Kata Kunci: Media Pembelajaran, PAUD, Pendidikan 


\section{A. Pendahuluan}

Dalam rangka meningkatkan pendidikan salah satunya pemerintah menerapkan pendidikan anak usia sejak dini, dengan suatu tujuan agar anak-anak Indonesia ketika melanjutkan pendidikan ke jenjang yang lebih tinggi sudah ada bekal persiapan, namun demikian untuk menunjang kebutuhan para anak-anak mendapatkan materi yang lebih mudah dan cepat di dapat tentunya lembaga harus menyiapkan media-media yang pas dan cocok untuk diterapkan pada anak-anak. Karena media yang tepat akan sangat membantu lembaga tersebut dalam mencapai suatu tujuan yang telah ditetapkan bersama.

Media memegang peranan penting dalam proses pembelajaran anak usia dini. Media dapat dijadikan sebagai wahana untuk mendekatkan persepsi dan pemahaman guru dengan daya tangkap anak. ${ }^{1}$ Dengan penggunaan media akan meningkatkan mutu dan kualitas pembelajaran, karena media memiliki fungsi untuk menjelaskan informasi/pesan yang disampaikan oleh pengirim pesan kepada si penerima pesan, yang dalam hal ini guru adalah sebagai pengirim pesan dan anak usia dini sebagai penerima pesan. Jadi dapat dikatakan bahwa media pembelajaran merupakan bagian yang integral dari seluruh sistem pembelajaran.

\section{B. Pengertian Media dan PAUD}

Media berasal dari bahasa latin dan merupakan bentuk jamak dari kata medium, secara harfiah mempunyai arti antara, perantara atau

${ }^{1}$ Rita Kurnia, Metodologi Pengembangan Bahasa Anak Usia Dini, Cet. 1, (Pekanbaru: Cendikia Insani, 2009), h. 221. 
pengantar. Media adalah perantara atau pengantar dari pengirim pesan ke penerima pesan. Terkait dengan pembelajaran media adalah segala sesuatu yang dapat digunakan untuk menyampaikan pesan dari pengirim pesan kepada penerima pesan sehingga dapat merangsang pikiran, minat dan perhatian anak didik untuk mencapai tujuan pendidikan yang optimal.

Ada beberapa batasan yang dikemukakan oleh para ahli tentang pengertian media yang dikutip Rita Kurnia menyatakan bahwa :

1. Gagne (1970)

Media adalah berbagai jenis komponen dalam lingkungan anak didik yang dapat memotivasi anak didik untuk belajar.

2. Schram (1977)

Media pembelajaran merupakan teknologi pembawa informasi yang dapat dimanfaatkan untuk proses belajar mengajar.

3. Briggs (1970)

Media pembelajaran adalah sarana fisik untuk menyampaikan materi pelajaran.

4. Gerlach \& Ely (1971)

Media apabila dipahami secara garis besar adalah manusia, materi atau kejadian yang membangun kondisi membuat murid mampu memperoleh pengetahuan, keterampilan atau sikap.

5. AECT (Association Of Education And Communication Thecnology) 1997)

Memberikan batasan tentang media sebagai bentuk dan saluran yang digunakan untuk menyampaikan pesan atau informasi.

6. Fleming (1987) 
Media adalah penyebab alat turut campur tangan dalam dua pihak atau mendamaikan.

7. Heinich dkk,(1982)

Mengemukakan istilah medium sebagai perantara yang mengatur formasi antara sumber dan penerima,

8. Hamidjodo Dalam Latuheru (1993)

Media adalah semua bentuk perantara yang digunakan oleh manusia untuk menyampaikan atau menyebarkan ide gagasan atau pendapat yang akan sampai kepada penerima yang dituju. ${ }^{2}$

Dari berbagai pendapat di atas tentang batasan pengertian media ,maka dapat disimpulkan bahwa pengertian media pembelajaran adalah segala bentuk alat komunikasi yang dapat digunakan untuk menyampaikan pesan/informasi dari sumber kepada anak didik yang bertujuan agar dapat merangsang pikiran, perasaan, minat dan perhatian anak didik untuk mengikuti kegiatan pembelajaran.

Sebelum memasuki pembahasan lebih lanjut berkenaan pendidikan anak usia dini (PAUD), baiklah jika didefinisikan lebih dahulu apakah yang dimaksud dengan PAUD itu sendiri, PAUD ialah jenjang pendidikan sebelum jenjang pendidikan dasar yang merupakan suatu upaya pembinaan yang ditujukan bagi anak sejak lahir sampai dengan usia 6 tahun yang dilakukan melalui pemberian rangsangan pendidikan untuk membantu pertumbuhan dan perkembangan jasmani dan rohani agar anak memiliki kesiapan dalam memasuki pendidikan

${ }^{2}$ Rita Kurnia, Media Pembelajaran Anak Usia Dini, (Pekanbaru: Bahan Ajar PAUD FKIP UR, 2014), h. 4. 
lebih lanjut, yang diselenggarakan pada jalur formal, nonformal, dan informal.

PAUD merupakan salah satu kebijakan strategis dalam pembangunan sumber daya manusia mengingat bahwa:

1. Usia dini ini merupakan masa keemasan (the golden age) namun sekaligus sebagai periode yang sangat kritis dalam tahap perkembangan manusia. Hasil penelitian mengungkapkan bahwa sampai usia 4 tahun tingkat kapabilitas kecerdasan anak telah mencapai 50\%. Pada usia 8 tahun mencapai 80\%, dan sisanya sekitar 20\% diperoleh pada saat anak berusia 8 tahun ke atas.

2. Pertumbuhan dan perkembangan anak pada usia dini sangat menentukan derajat kualitas kesehatan, intelegensi, kematangan emosional dan produktivitas manusia pada tahap berikutnya. Dengan demikian pengembangan anak usia dini merupakan investasi sangat penting bagi Sumber Daya Manusia yang berkualitas. $^{3}$

Berdasarkan kajian di atas, maka pemerintah menerbitkan Undang-Undang SISDIKNAS Nomor 20 Tahun 2003 tentang Sistem Pendidikan Nasional pasal 1 butir 14 menyatakan bahwa "Pendidikan anak usia dini adalah suatu upaya pembinaan yang ditujukan kepada anak sejak lahir sampai dengan usia enam tahun yang dilakukan melalui pemberian rangsangan pendidikan untuk membantu pertumbuhan dan perkembangan jasmani dan rohani agar anak

${ }^{3}$ Hamid Muhammad, Pedoman Penyelenggaraan PAUD Terpadu, (Jakarata: Dirjen Pembinaan PUDNI, 2012), h. 1. 
memiliki kesiapan dalam memasuki pendidikan lebih lanjut". ${ }^{4}$ Batasan lain mengenai anak usia dini pada anak berdasarkan psikologi perkembangan yaitu usia 0-8 tahun. Di samping istilah pendidikan anak usia dini terdapat pula terminologi pengembangan anak usia dini yaitu upaya yang dilakukan oleh masyarakat atau pemerintah untuk membantu anak usia dini dalam mengembangkan potensinya secara holistic baik aspek pendidikannya, gizi maupun kesehatannya. ${ }^{5}$ Lebih lanjut pada pasal 28 dinyatakan bahwa pendidikan anak usia dini dapat diselenggarakan melalui jalur pendidikan formal, nonformal, dan informal. PAUD pada jalur pendidikan formal dapat berupa Taman Kanak-Kanak dan (TK) /Raudathul Atfhal (RA).

Adapun PAUD pada jalur pendidikan nonformal dapat berupa Kelompok Bermain (KB), Taman Penitipan Anak (TPA), atau bentuk lain yang sederajat. Pendidikan anak usia dini merupakan salah satu bentuk penyelenggaraan pendidikan yang menitik beratkan pada peletakan dasar ke arah pertumbuhan dan perkembangan fisik. (Koordinasi motorik halus dan kasar), kecerdasan (daya fikir, daya cipta, kecerdasan emosi, kecerdasan spiritual, sosio- emosional (sikap dan perilaku serta agama) bahasa komunikasi, sesuai dengan keunikan dan tahap- tahap perkembangan yang dilalui oleh anak usia dini. ${ }^{6}$

Tujuan utama diselenggarakanya PAUD yaitu,

\footnotetext{
${ }^{4}$ Undang-Undang Nomor 20, Tentang Sistem Pendidikan Nasional, Tahun
} 2003, pasal 1 butir 14 .

${ }^{5}$ Direktorat PADU, Tahun 2002, h.3.

${ }^{6}$ Danar Santi, Pendidikan anak usia dini, (PT. Matana Jaya Cemerlang, 2009), h.1-3. 
1. Membentuk anak Indonesia yang berkualitas, yakni anak yang tumbuh dan berkembang sesuai dengan tingkat perkembangannya sehingga memiliki kesiapan yang optimal didalam memasuki pendidikan dasar serta mengarungi kehidupan di masa dewasa.

2. Tujuan penyerta: membantu menyiapkan anak mncapai kesiapan belajar( akademik) di sekolah. Rentangan anak usia dini adalah 0-6 tahun. ${ }^{7}$

Belajar sambil bermain adalah sistem pendidikan yang umum diterapkan disetiap lembaga pendidikan usia dini. Sistem ini telah lama diImplementasikan di Indonesia, utamanya diterapkan tokoh pendidikan sekaligus penyayang anak-anak, pak Kasur yang bernama lengkap Soerjono seorang tokoh pendidikan Indonesia. Pusat, teori dan praktek pendidikan yang diterapkan ialah memadukan cara mengajar" bermain sambil belajar" yang memadukan kurikulum yang digariskan oleh pemerintah yaitu:

1. Cara mengajar melalui nyanyian.

2. Membuat alat peraga untuk keperluan sekolah dengan bahan sederhana

3. Permainan yang dibuat dan diberikan pada anak yang bertujuan untuk keterampilan

4. Upacara hormat bendera yang dilakukan setiap pagi sebelum dimulai sekolah.

Dunia anak adalah dunia bermain, dan belajar dilakukan dengan sambil bermain yang melibatkan semua alat indra anak. Sebagian

${ }^{7}$ UU Sistem Pendidikan Nasional No 20/2003 pasal 28, ayat 1. 
pembelajaran terpenting dalam kehidupan diperoleh dari masa kanakkanak paling awal, dan pembelajaran ini sebagian besar diperoleh dari bermain, sayangnya bermain sebagai gagasan yang dikaitkan dengan pembelajaran kurang mendapat apresiasi dalam berbagai lingkungan budaya. Bermain bagi anak adalah kegiatan serius tetapi menyenangkan.Bemain adalah aktivitas yang dipilih sendiri oleh anak karena menyenangkan, bukan karena hadiah atau pujian. Melalui bermain semua aspek perkembangan anak dapat ditingkatkan karena dengan bermain anak secara bebas dapat berkespresi dan bereksplorasi untuk memperkuat hal-hal yang sudah diketahui dan dapat menemukan hal-hal yang baru. Melalui permainan anak juga dapat mengembangkan semua potensi secara optimal, baik potensi fisik maupun amental intelektual dan agama. Oleh karena itu bermain bagi anak merupakan jembatan bagi perkembangan tumbuh kembangnya.

\section{Peran dan Fungsi Media Pembelajaran PAUD}

Media pembelajaran merupakan wadah dari pesan yang disampaikan oleh sumber atau penyalurnya yaitu guru kepada sasaran atau penerima pesan yakni siswa kanak- kanak yang sedang melakukan pendidikan. Mengutip pendapat Azar menyatakan bahwa media pembelajaran pendidikan secara umum dapat diartikan sebagai sarana atau prasarana yang dipergunakan untuk membantu tercapainya tujuan pembelajaran, secara khusus media pembelajaran sebagai alat, metode, dan teknik yang digunakan dalam rangka lebih mengefektifkan 


\section{Asmariani}

komunikasi dan interaksi antara guru dan siswa dalam proses pembelajaran dan pengajaran di sekolah. ${ }^{8}$

Media dapat dimanfaatkan untuk menyampaikan bagian tertentu dari kegiatan pembelajaran, memberikan penguatan maupun motivasi. Kembali kepada arti penting media dalam proses belajar mengajar yang dapat mengantarkan kepada tujuan pendidikan. Maka berikut ini akan diuraikan berbagai peranan media dalam proses belajar mengajar menurut Hamalik adalah sebagai berikut :

1. Memperjelas penyajian pesan dan mengurangi verbalitas

2. Memperdalam pemahaman anak didik terhadap materi pelajaran

3. Memperagakan pengertian yang abstrak kepada pengertian yang konkrit dan jelas

4. Mengatasi keterbatasan ruang, waktu dan daya indra manusia

5. Penggunaan media pembelajaran yang tepat akan dapat mengatasi sikap pasif. ${ }^{9}$

Sedangkan menurut Hamalik peranan media dalam proses belajar mengajar adalah untuk :

1. Mengatasi sifat unik pada setiap anak didik yang diakibatkan oleh lingkungan yang berbeda.

2. Media mampu memberikan variasi dalam proses belajar mengajar.

3. Memberikan kesempatan pada anak didik untuk mereview pelajaran yang diberikan.

8 Azar Arsyad, Media Pembelajaran, (Jakarta: PT.Raja Brafindo persada,2003), h.1-2.

9 Arief Sadiman, Media Pembelajaran: Pengertian, Pengembangan dan Pemanfaatannya, (Jakarta: Pustekkom Dekdikbud Clan PT.Raja Grafindo Persada), h.12. 
4. Memperlancar pelaksanaan kegiatan belajar mengajar dan mempermudah tugas para guru.$^{10}$

Pemakaian media dalam proses pembelajaran dapat meningkatkan keinginan dan minat yang baru, membangkitkan motivasi dan rangsangan kegiatan belajar dan juga berpengaruh pada psikologi anak. Anak merasa nyaman dengan kegiatan pembelajarannya karena terkesan tidak dipaksa, dengan kata lain anak merasa belajar sambil bermain.

Untuk mamahami secara komprehensif manfaat diadakannya media dalam pembelajaran PAUD, maka akan disajikan fungsi media pembelajaran PAUD menurut Levie \& Lentz yang penulis kutip dari buku Rita Kurnia menyatakan bahwa :

1. Fungsi Atensi yaitu : menarik dan mengarahkan perhatian murid pada isi pelajaran dibantu dengan media gambar sehingga memiliki kemungkinan mengingat isi pelajaran lebih besar.

2. Fungsi Afektif yaitu muncul ketika belajar dengan teks yang bergambar, sehingga dapat menggugah emosi dan sikap murid.

3. Fungsi Kognitif yaitu mengungkapkan gambar, memperlancar pencapaian tujuan memahami dan mengingat informasi yang terkandung.

4. Fungsi konpensatoris yaitu berfungsi mengakomodasikan murid yang lemah dan lambat menerima dan memahami sisi pelajaran yang disajikan dengan teks. ${ }^{11}$

${ }^{10}$ Oemar Hamalik, Media Pendidikan, (Bandung: Alumni ), h.9.

${ }^{11}$ Rita Kurnia, Media Pembelajaran Anak Usia Dini,(tt), h.7. 


\section{Asmariani}

Untuk memahami peranan media dalam proses mendapatkan pengalaman belajar bagi murid, Edgar Dale melukiskan yang dalam sebuah kerucut yang kemudian dinamakan kerucut pengalaman ini dianut secara luas untuk menentukan alat bantu atau media apa yang sesuai agar murid memperoleh pengalaman belajar secara mudah. Kerucut pengalaman ini memberikan gambaran bahwa pengalaman belajar yang diperoleh murid dapat dilalui proses perbuatan atau mengalami sendiri apa yang dipelajari, proses mengamati dan mendengarkan melalui media tertentu dan proses mendengarkan melalui bahasa.

Semakin konkrit murid mempelajari bahan pengajaran, contohnya melalui pengalaman langsung, maka semakin banyaklah pengalaman yang diperolehnya. Sebaliknya semakin abstrak murid memperoleh pengalaman, contohnya hanya mengandalkan bahasa verbal, maka semakin sedikit pengalaman yang akan diperoleh murid.

Berdasarkan atas beberapa fungsi media pembelajaran yang dikemukakan oleh para ahli, dapat disimpulkan bahwa penggunaan media pembelajaran dalam kegiatan belajar mengajar memiliki pengaruh yang cukup besar terhadap fungsi alat indra murid. Penggunaan media akan lebih menjamin terjadinya pemahaman dan retensi yang lebih baik terhadap isi pelajaran. Media pembelajaran juga mampu membangkitkan dan membawa murid ke dalam suasana senang dan gembira, ada keterlibatan emosional dan mental. Tentu hal ini berpengaruh terhadap semangat mereka untuk lebih giat dalam belajar sehingga dapat memberikan kesan pembelajaran yang hidup, akhirnya bermuara kepada peningkatan pemahaman belajar anak terhadap materi 
ajar. Jadi sasaran akhir media adalah memudahkan belajar untuk murid, bukan hanya kemudahan mengajar oleh guru.

\section{Faktor Penentu dalam Pemilihan Media PAUD}

Ragam media pembelajaran tentunya tidak akan digunakan seluruhnya secara serantak dalam kegiatan pembelajaran, Untuk itu perlu dilakukan pemilihan media tersebut. Untuk membuat media pembelajaran, harus mempertimbangkan media tersebut. Dalam kriteria untuk mempertimbangkan guru atau pendidik kaitanya dalam pemilihan media pembelajaran anak-anak.

Pembelajaran yang efektifitas memerlukan perencanaan yang baik. Media yang akan digunakan dalam proses pembelajaran itu juga memerlukan perencanaan yang baik pula. Faktor-faktor yang perlu disikapi dalam pemilihan media pembelajaran adalah: a) komunikatif, b) harganya yang murah, c) nilai kepraktisanya dan d) kondisi pemakainya. Untuk memilih media secara efektif Romis zowski, menyebutkan faktor-faktor yang mempengaruhi dalam memilih media pembelajaran yaitu: 1) metode pembelajaran yang digunakan; 2) tujuan pembelajaran; 3) karakteristik pembelajaran; 4) aspek kepraktisanya (biaya dan waktu); 5) faktor pemakaian. Secara umum media pembelajaran mempunyai kegunaan diantaranya: 1) memperjelas penyajian pesan, 2) mengatasi keter belakangan ruang, 3) mengatasi sifat pasif siswa. Dalam meningkatkan kualitas proses pembelajaran dan hasil pembelajaran, kita tidak boleh melupakan suatu hal yang sudah pasti kebenarannya, bahwa pembelajar harus sebanyakbanyaknya berinteraksi pada sumber belajar ( buku, internet, yang 
berhubungan dengan pengetahuan). Tanpa sumber belajar yang memadai sulit diharapkan suatu proses pembelajaran yang mengarah kepada tercapainya hasil belajar yang optimal. ${ }^{12}$

Dengan demikian penggunaan media sebagai sumber belajar dalam kegiatan pembelajaran mempunyai arti yang sangat penting. Media pembelajaran yang dapat membangkitkan minat, perhatian, dan kreativitas siswa hendaknya menggunakan media yang menarik dan sesuai dengan karakteristik siswa sehingga dapat memotivasi semangat belajar. Aspek kemenarikan ini bisa dilakukan dengan pemilihan materi dan desain penyajian media. Berdasarkan jenis di atas, anak-anak yang duduk dibangku sekolah dimana kelak mereka akan terjun ke masyarakat. Di era globalisasi ini menuntut sumber daya manusia kita untuk bersaing sesuai dengan perkembangan zaman. Sehingga siswa dalam usia ini gemar membentuk kelompok bermain usia sebaya.

\section{E. Prinsip- Prinsip Pembuatan, Penggunaan dan Pengembangan Media PAUD}

Pembuatan media pembelajaran berbasis teknologi informasi dan komunikasi dalam program pendidikan anak usia dini haruslah terjadi pemenuhan berbagai macam kebutuhan anak, mulai dari kesehatan, nutrisi, dan stimulasi pendidikan, juga harus dapat meberdayakan lingkungan masyarakat dimana anak itu tinggal. Prinsip

12 Ali Sumarno, "Kriteria Pemilihan Media", dikutip dari http://alimsumarno.blog.unesa.ac.id/artikel/kriteria-pemilihan-media/ pada tanggal 22 Maret 2016, jam 10:20 WIB. 
pelaksanaan program pendidikan anak usia dini harus mengacu pada prinsip umum yang mengandung dalam konfensi hak anak, yaitu:

1. Non diskriminasi, dimana semua anak dapat mengecap pendidikan usia dini tanpa membedakan suku bangsa, jenis kelamin, bahasa, agama, tingkat sosial,serta kebutuhan khusus setiap anak.

2. Dilakukan demi kebaikan terbaik untuk anak (the best intenrest of the child), bentuk pengajaran, kurikulum, yang diberikan harus disesuaikan dengan tingkat perkembangan kognitif, emosional, konteks sosial budaya dimana anak-anak hidup.

3. Mengakui adanya hak hidup, kelangsungan hidup dan perkembangan yang sudah melekat pada anak.

4. Penghargaan terhadap pendapat anak ( respect for the views of the child), pendapat anak terutama yang mana menyangkut kehidupannya perlu mendapatkan perhatian dan tanggapan.

Prinsip pembuatan media pendidikan anak usia dini harus sejalan dengan prinsip pelaksanaan keseluruhan proses pendidikan seperti yang dikemukakan oleh Damanhuri Rosadi yang dikutif oleh Mansur menyatakan bahwa Pendidikan anak usia dini dalam Islam ada delapan prinsip tersebut diantaranya sebagai berikut:

1. Pengembangan diri, pribadi, karakter, serta kemampuan belajar anak diselenggarakan secara tepat, terarah, cepat dan berkesinambungan.

2. Pendidikan dan pengembangan anak mencakup upaya meningkatkan sifat mampu mengembangkan diri dalam anak.

3. Pemantapan diri yang dihayati oleh anak sesuai sistem dalam masyarakat. 
4. Pendidikan anak adalah usaha sadar, usaha yang menyeluruh, terarah, terpadu dan dilaksanakan secara dan saling menguatkan oleh semua pihak yang terpanggil

5. Pendidikan anak adalah suatu upaya yang berdasarkan kesepakatan sosial seluruh lapisan dan golongan masyarakat.

6. Anak mempunyai kedudukan sentral dalam pembangunan, dimana PAUD memiliki makna strategis dalam pembangunan sumberdaya manusia

7. Orang tua dalam keteladanan adalah pelaku utama dan pertama komunikasi dalam PAUD

8. Program PAUD harus melingkupi inisiatif berbasis orang tua, berbasis masyarakat, dan institusi formal sekolah. ${ }^{13}$

Dengan demikian ada beberapa prinsip umum tentang pendidikan anak usia dini. Anak adalah individu yang unik, tugas pendidik baik tutor maupun orang tua adalah memberi pengarahan yang positif bagi perkembangan anak, memberi peluang untuk berubah, dan bukan mematikan dengan memberi cap negatif pada anak. Perkembangan anak berkembang secara bertahap dan berkesinambungan. Usia anak merupakan masa kritis. Semua aspek perkembangannya saling berhubungan bakat dan lingkungan saling mempengaruhi perkembangan anak. Perilaku anak tergantung pada motivasi atau stimulan dari dalam dan luar dirinya. Perkembangan intelegensi juga bergantung pada pola pengasuhan. Perkembangan anak tergantung pada hubungan antara pribadi, kesempatan

13 Mansur, Pendidikan anak usia dini dalam Islam (Yogyakarta: Pustaka Pelajar, 2009), h. 100-103. 
mengekspresikan diri dan bimbingan pada tiap tahap perkembangan anak. Berdasarkan uraian di atas keluarga adalah tempat yang sangat penting bagi pelaksanaan pendidikan anak usia dini, sebab keluarga merupakan pendidikan yang utama dan pertama bagi anak dalam rangka mengembangkan potensi yang dimiliki. Setiap anak pada dasarnya memiliki komunikasi dengan orang lain dan potensi lainya, sehingga untuk mengembangkan potensi tersebut diperlukan bimbingan dari orang tua, pendidik atau orang dewasa lainya supaya memperoleh hasil maksimal dan positif, pengembangan potensi tersebut harus dimulai sejak usia dini, sebab pada usia tersebut merupakan dasar untuk perkembangan berfikir pada masa berikutnya.

\section{F. Kesimpulan}

Media pembelajaran adalah segala bentuk alat komunikasi yang dapat digunakan untuk menyampaikan pesan/informasi dari sumber kepada anak didik yang bertujuan agar dapat merangsang pikiran, perasaan, minat dan perhatian anak didik untuk mengikuti kegiatan pembelajaran.

Penggunaan media pembelajaran dalam kegiatan belajar mengajar memiliki pengaruh yang cukup besar terhadap fungsi alat indra murid karena akan lebih menjamin terjadinya pemahaman dan retensi yang lebih baik terhadap isi pelajaran. Media pembelajaran juga mampu membangkitkan dan membawa murid ke dalam suasana senang dan gembira, terjadi adanya keterlibatan emosional dan mental murid. Tentu hal ini berpengaruh terhadap semangat mereka untuk lebih giat dalam belajar sehingga dapat memberikan kesan pembelajaran yang 
hidup, akhirnya bermuara kepada peningkatan pemahaman belajar anak terhadap materi ajar. Jadi sasaran akhir media adalah bukan hanya kemudahan mengajar oleh guru namun memudahkan belajar juga untuk murid.

Fungsi media dalam pembelajaran PAUD adalah sebagai : Atensi, Afektif, Kognitif, Konpensatoris. Adapun faktor-faktor yang perlu disikapi dalam pemilihan media pembelajaran adalah: a) komunikatif , b) harganya yang murah, c) nilai kepraktisanya dan d) kondisi pemakaianya. 


\section{DAFTAR PUSTAKA}

Arsyad, Azar. 2005. Media Pembelajaran, Jakarta: PT.Raja Brafindo Persada.

Direktorat PADU, Tahun 2002.

Hamalik, Oemar. tt., Hamalik, Media Pendidikan, Bandung, :Alumni.

Kurnia, Rita. 2009. Metodologi Pengembangan Bahasa Anak Usia Dini, Pekanbaru, Cendikia, Insani.

. 2014. Media Pembelajaran Anak Usia Dini, Pekanbaru, Bahan Ajar PAUD FKIP UR.

Mansur. 2009. Pendidikan Anak Usia Dini dalam Islam, Yogyakarta,Pustaka Pelajar.

Muhammad, Hamid. 2012. Pedoman Penyelenggaraan PAUD Terpadu, Dirjen Pembinaan PUDNI.

Sadiman, Arief. Media Pembelajaran : Pengertian, Pengembangan dan Pemanfaatannya, Jakarta: Pustekkom Dekdikbud Clan PT.Raja Grafindo Persada.

Santi, Danar. 2009. Pendidikan Anak Usia Dini, PT. Matana Jaya Cemerlang.

Seefeldt, Carool. 2008., Pendidikan Anak Usia Dini, Jakarta: PT macanan jaya cemerlang.

UU sistem pendidikan nasianal No 20/2003 pasal 28, ayat 1 UndangUndang Nomor 20, Tentang Sistem Pendidikan Nasional, (Tahun 2003) pasal 1 butir 14. 